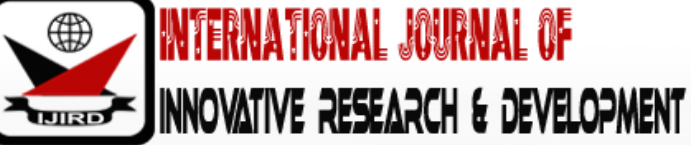

ISSN 2278 - 0211 (Online)

\section{Historical Trends on the Farmer-Herder conflict in Kitui East Sub County, Kenya, 1895-2013}

\author{
Winnifred Wambui Mwikali \\ Ph.D. Student, School of Arts and Social Sciences, Moi University, Eldoret, Kenya \\ Diperus Wafula Wanyonyi \\ Ph.D. Student, School of Arts and Social Sciences, Moi University, Eldoret, Kenya \\ Beatrice Nyabonyi Munge \\ Ph.D. Student, School of Arts and Social Sciences, Moi University, Kenya
}

\begin{abstract}
:
There is an upsurge of farmer-herder conflicts in Kenya. These conflicts involve two claimant groups fighting over access to limited natural resources like pasture and water. Available data indicates that these conflicts have existed since pre-colonial period. However, they intensified during and after the colonial era. National occurrences and trends have played a crucial role in the occurrence of these conflicts. The conflicts have in turn led to socio-economic transformations in the region. The objective of the study was to trace the historical trends on farmer-herder conflict in Kitui East Sub County in the period 1963-2013. The study was guided by the theory of structural violence by John Galtung which states that structural violence leads to structural inequalities which in turn lead to violent conflicts. In this study, 200 respondents were selected using Simple random sampling technique. Key informants who included; community members, community elders, members of the Area Peace Development committees, state security agents, Non-Governmental Organizations and religious leaders were then selected using Purposive sampling procedure. The study used Questionnaire, interview schedules, Focused Group Discussions and archival sources to get Primary data. Document analysis was done to give secondary data related to the study. The data was then analyzed using descriptive statistics. The results were presented in narration form. The study established that national historical trends have influenced the occurrence of the farmer-herder conflicts that have been witnessed in Kitui East Sub County. It is expected that the outcomes of this study will go a long way into building the historiography on conflicts in Kenya, East Africa and the continent as a whole, inspiring other scholars and researchers and acting as reference resource book for other scholars.
\end{abstract}

Keywords: Conflict, farmer-herder, historical trends, Kitui East Sub County

\section{Introduction}

Peaceful coexistence of communities and their socio-economic development go hand in hand, while conflict and socio-economic decline of communities are also two faces of the same coin. This means that where there is peace and security local communities will be encouraged to invest in productive socio-economic which in turn will give employment and enhance socio-economic development to individuals, communities and the entire nation. Thus, peace and security stimulate socio-economic development. On the contrary, conflict leads to war hence undermining food production, which will further culminate to socio-economic decline. Cramer, (2006) while giving a comparison between conflict and development shows that violent conflicts and underdevelopment mutually affect and reinforce one another. For instance, Collier et al. (2003) have concluded that violent conflict retards development, but conversely, development retards war (conflict). In other words, violent conflict has an impact on the national, local as well as domestic economies of a conflict area. Justino (2007)puts it more succinctly: "violent conflict will affect the levels of poverty in any given economy, as well as the dynamics of poverty along the lifetime of the conflict and in post-conflict context."

The above studies indicate that conflict and poverty are self-reinforcing. This means that conflicts lead to poverty and in turn poverty leads to conflicts. This condition leads to a vicious circle of conflicts and poverty in the affected region. As such, there is need for the government to ensure socio-economic development of each community to avoid these conflicts. However, the past regimes in Kenya have done little to avert the conflicts. Instead, the government itself has played a crucial role in the escalation of conflicts during the colonial and post-colonial period. The regimes that have been there in the past have marginalized the local communities in Kitui East Sub County. This marginalization has led to lack of water and pasture leading to conflicts. Therefore, the theoretical framework of structural violence by Galtung (1990) exemplify the communities' relations which have seen them involved in perennial conflicts among themselves, a situation that has led to vicious cycle of poverty and under development. 
Although conflicts in Kenya are of many different kinds, Juma (2000) has classified them into four main categories: Conflicts among pastoral communities, Conflicts linked to presence of refugees, conflicts between farmers and herders 'communities and ethnic clashes. This work focused on the conflict between the farmers and the herders, which is characterized by disputed claims between rival claimants; in this case Akamba farmers and Somali and/ or Oromo herder communities over pasture and water. Over the recent past, conflicts involving these two communities have been on the rise. In support of this view, Adams and Bradbury, (1992) have observed that conflict over natural resources between farmers and herders are noted to be a chronic problem. In the same vein, Seddon, and Sumberg, (2010) note that the need for local communities to resort to such violence is indicative of a lack of policies, or that existing policies are not working to the benefit of these communities as a whole hence the increased conflicts.

In Kitui East Sub County of Kitui County which is the focus of the study, the most perennial and potentially violent form of conflict has been between the Akamba farmers on one side and the Somali and Oromo communities on the other side. The most affected areas are Syou, Katumbi, Malalani, Twambui and Makuka.According to the CARITUS Kitui report (2012), these conflicts have been triggered by competition over water and pasture. The conflicts have been directly responsible for increased deaths, destruction of property, poverty, hunger, starvation, disease, fear, suspicion, mistrust, insecurity and general hopelessness in the Kitui East Sub County. They have thus been detrimental to public peace and security which are pillars to socio-economic development.

\subsection{Kitui East Sub County}

The area lies between the central highlands of Kenya and the coastal forests. The altitude ranges from $500 \mathrm{~m}$ above the sea level. In the dry lowlands to 1,400 m above the sea level at the highest peak. It has a total area of 368 square kilometers. It has a population of 88,000 people (Mwendwa, 2014). The Sub County borders Mutomo to the East, Kitui West Sub County to the West, Kitui Rural to the South and Mwingi to the North. It has two major towns which are Mutitu and Zombe. The latter is the head quarter of the Sub County. It is the epicenter of the contact and hostility between the Akamba farmers and the herder communities (Somali and Oromo). It is in this sub county where the Somali and Oromo migrate during the drier seasons. Enziu River which is the source of conflict drains the Sub County under study. The Akamba farmers use the river water to irrigate their farms, while the same river provides water for Somali and Oromo herds. It is semi-arid with the main economic activities being subsistence farming (cultivation and animal keeping). The poverty levels in the sub county are high leading to increased competition for natural resources, hence escalation of conflicts.

\subsection{The Peopling of Kitui East Sub County}

During the pre-colonial period, Kitui East Sub County was predominantly inhabited by the Akamba people, but over the years, ethnic diversity was witnessed in the study area as Somali and Oromo herders immigrated from the neighboring Garissa and Tana River counties in search of water and pasture for their animals. In a research done by Opiyo et al (2011) the population of Akamba community was found to be the highest (67\%) in the area followed by Somali with 20 percent and Oromo with 13 percent respectively. The arrival of the herder groups caused resource use conflict in the sub county. The result has been perennial violent conflicts that have led to social and economic transformations among the local communities that are worth investigating.

\subsection{Theoretical Framework}

The study was guided by the Structural Violence Theory. This theory was advanced by Galtung (1969) to articulate the link between social structures and human suffering and death. He defines structural violence as avoidable impairment of fundamental human needs or, to put it in more general terms, the impairment of human life, which lowers the actual degree to which someone is able to meet their needs below that which would otherwise be possible. Unequal accesses to resources, to political power, to education, to health care, or to legal standing, are forms of structural violence. In Sens (1999) view, another proponent of structural theory, Poverty which is a result of structural violence, clearly places individuals at a much higher risk of malnourishment, disease and death. It is clear from these indicators that 'severe poverty cause's massive under fulfillment of social and economic human rights, such as the "right to a standard of living adequate for the health and well-being of oneself and one's family, including food, clothing housing and medical care. Poverty then, is 'the failure of basic capabilities to reach certain minimally acceptable levels', where basic capabilities are understood as basic freedoms 'such as the freedoms to avoid hunger, disease, illiteracy, and so on.

According to Sengupta (1999) who is also a strong proponent of the structural violence theory, the right to development is a vector that consists of each of the human rights, and its value is also dependent upon development of infrastructure. Looking at the water scarcity in Kitui East Sub County of Kitui County it's clear that the Sub County has been neglected by the government. There has been very little investment in piped water provision, despite there being several permanent water sources on the hill within only a few kilometers distance from most villages. Interesting to note is that there are currently only three functional or partly functional water pipelines, supplying villages to the west and south of the Endau hill. Several other water projects failed due to corruption among the organizations carrying out the project, poor quality of pipes and poor engineering, as well as lack of maintenance. Notably, the drier areas to the east and north of the Endau hill, including Malalani, have been unable to complete water projects that were started. This has led to the two user groups (Somali and/ or Orma herders and Akamba farmers) fighting over the limited resources which in turn has led to loss of livelihoods, reduced access to education and health care and also dependency.

The above observation indicates past government policies have marginalized people in Kitui East Sub County of Kitui which is a dry land, contributing to geographical social inequities, not only by restricting people's livelihoods as 
described above but also by poor provision of infrastructure. This view is also supported by CICERO Report (2006) which shows that the dry lands have been seen as having low economic potential and being politically unimportant, as a result, government allocations for development in the dry lands have often been low. Lind and Eriksen (2006) Point out that the post-colonial government did not seriously focus on problems relating to soil erosion and water development until the 1974-1978 development plans.

However as has been frequently pointed out, the notion of structural violence is too broad. It neglects the specific differences in historical variations of forms of injustice, their intersections and the ways in which they are compounded. Slavery, racism, sexism, colonialism and class dominance as well as other disparities, are collapsed into a single category. In the study area for instance, the theory fails to justify the occurrence of conflicts which were there even during the precolonial period.

\section{Methodology}

\subsection{Research Design}

The study adopted the descriptive survey design which is appropriate because it does not manipulate variables or arrange for events to happen (Orodho, 2003). It is an appropriate means of collecting information when both quantitative and qualitative data is required. The design is more concerned with description and narration of facts and characteristics of a given situation. The design was also preferred because it facilitates accurate collection of views, suggestions and opinions regarding impacts of farmer-herder conflict on socio-economic development of the local communities in Kitui East Sub County.

\subsection{Sampling Procedure and Sample Size}

There are 30 County villages units in Kitui East Sub County.Kitui County Villages Bill (2014). According to Mugenda and Mugenda (2003) at least 30\% of the total population is a representative of the whole population. Thus, 30\% of the 30 villages gave a total of 9 villages. Purposive sampling was used to select the County village units that had witnessed frequent conflicts. Using this method, ten villages were selected for the study.

\subsection{Data collection procedure}

Interviews were held with key respondents to gather expert opinion about conflicts from people with special knowledge. The experts formed the key respondents in the study. This included government security agents, religious leaders and officials of Non-Governmental Organizations. The interviewer probed the respondents through conversation and questions. The interview schedules were ideal to the researcher because information was obtained from the respondents directly. The researcher was therefore able to probe the respondents for clarification in case of ambiguous responses. This allowed the researcher to explain the subject of discussion clearly and accommodate both literate and illiterate members of the community to respond to questions. According to Borg and Gall (2007), interviewing allows the researcher to probe the respondent on desired issues. Unlike other methods of gathering information, interviewing gives a chance to the researcher to make inferences from what the respondent says both verbally and non-verbally. This method solely used to find out the knowledge of the government security agents, religious leaders and NGOs officials about the farmer-herder conflicts.

In addition to the interviews, focus group discussions (FGDs) were held. They were held with Community members, Members of Area Peace Development committees and Local Community Leaders. The FGDs provided in-depth information that could not be captured by other instruments. They were used to crosscheck some information obtained through questionnaires and also to save on time. Focus Group Discussions (FGDs) was used to elicit information from the community members. This is a form of group interview mostly triangulated with more traditional forms of interviewing, questionnaire, and observation Cohen, Manion \& Morrison (2007) observe that this method is good in obtaining several perspectives about the same topic. It facilitates easy conceptualization of the gap between what people say and what they do.

\subsection{Data Analysis Procedure}

Qualitative approach was used for data analysis. The qualitative data which was obtained from interview schedule and FGDs and reported in narrative form.

\subsection{Ethical Considerations}

Prior to the commencement of data collection, the researcher obtained all the necessary documents, including an introduction letter from Kibabii University to seek the research permit from National Commission of Science and Technology. Audience with the sampled respondents in the study area was also sought to clarify the purpose of the study. Upon getting clearance, the researcher in person distributed the questionnaires to the sampled individuals. Assistance from the local administrative offices was also sought. The researcher explained to the respondents about the research. The researcher assured the respondents that the study was for academic purposes only. The role of the research guides (Matoma Mutua and Kalamba Musau) was clearly defined. It was made clear that the participation was voluntary and that the respondents were free to decline or withdraw any time during the research period. Respondents were not coerced into participating in the study. The participants had informed consent to make the choice to participate or not. They were guaranteed of confidentiality of their responses. Permission was also sought from respondents to use their photographs and verbatim captions in this thesis. 


\section{Findings of the Study}

The study was conducted in Kitui East Sub County with 200 respondents participating in the study. Primary data was collected using a questionnaire, interview schedules and FGDs. Secondary data was obtained from document analysis. The objective was to trace the historical trends on the farmer-herder conflicts in Kitui East Sub County in the period 18952013.

\subsection{Historical Trends on the Farmer-Herder Conflict in Kitui East Sub County, Kenya, 1895-2013}

The objective of the study was to examine the historical trends of farmer-herder conflict in Kitui East Sub County of Kitui County. The study classified the historical trends in four categories. This was done according to historical chronology. They included the; Colonial government, Jomo Kenyatta's era, Daniel Moi's era and Mwai Kibaki's era.

\subsection{The Colonial Era (1895 - 1963)}

To understand problems in a particular society during the colonial era, it is necessary to examine the impact of colonialism on that society. It is necessary, for example, to investigate the effects of commodity production on the society's social structure and how changes in the social structure were manifested in food shortages. Similarly, the impact of labor migration on food production needs to be looked into. In sum, the gradual incorporation of Kenyan societies into the capitalist system through the colonial state progressively led to a crisis in pre-existing systems of production and distribution. (Matheka, 1992). The introduction of the capitalism mode of production by the colonial government led to change in the interaction between the farmers and the herders which in turn led to violent conflicts. Initially, the Akamba who were the initial inhabitants of the study area coexisted peacefully with the immigrating herders safe for some occasional cattle raiding.

CICERO report (2006) shows that the early inhabitants of Mutitu sub of Kitui County were the Akamba whose settlement began as the agro-pastoralist from the Akamba ethnic group came to search for pasture and water. The sub county was predominantly inhabited by the Akamba people, but over the years, ethnic diversity has been witnessed in the study area as Somali and Oromo herders have immigrated from the neighboring Garissa and Tana River counties in search of water and pasture for their animals. (Mwikali, 2018)

Before the era of colonialism, the Africans tenure system depended on expanses of open, communally held pastureland which both the farmers and the herders shared with minimal conflicts. In the colonial period, there was an extensive land seizure and enclosure program.

With the advent of colonialism, the colonial government came up with the infamous colonial land policies which aimed at creating white highland for the white settlers. This mode of colonial economy necessitated deliberate land alienation from African communities through colonial land policies. This is according to Ochieng, (1989). Some of the colonial land policies included the Land Regulation Act of 1897 which gave settlers certificates of occupancy for 99 years, The East African Land Order in Council of 1901 defined crown land as all public land that is not private. Private land included land occupied by the Europeans and Africans. The Crown Land Ordinance of 1902 said that all empty land could be sold at two rupees per acre or rented out at fifteen rupees per 100 acres per to Europeans. In 1904, the first African reserve was created for the Maasai. Consequently, by 1920, land not owned by Europeans eventually became crown land. Africans owned no land according to the European law. (Were, \& Wilson, 1987) subsequently, by 1920, the Akamba had lost effective access to about two-thirds of the land they had formerly controlled including their most fertile lands and half of all their pasture. Along with some of their best grazing land, they lost the freedom to migrate seasonally and periodically in search of water, pasture, and cropland (Munro, 1975). Although the study region was not part of the white highlands, the people who were evicted from the white highlands moved to this area leading to overpopulation. For the communities in Kitui East Sub County, the crisis of the era was one of land alienation, as settlers disrupted their tenure system and took away their land. At the same time, the state barred the herders from movement which deprived them the freedom to seek for pasture for their animals.

Following the above land laws, the Africans were therefore moved to the reserves. The results of that were over population and overcrowding of the Africans in the reserves. Due to the limited land in the African reserves, there was also overgrazing which led to serious soil erosion. Simiyu (1974)avers that, the colonial officials blamed the Akamba backward cattle rearing methods and their primitive crop production methods for the problem. Colonial officials and observers, while recognizing the epidemics, blamed Akamba cattle-rearing practices as well as their "primitive" standard of living for the magnitude of the disaster. To counter the soil erosion problem, the colonial government came up with soil erosion control measures. Here, colonial policies focused on soil erosion control, terracing, protection of riverbanks and other environmental protection measures. Consequently, the colonial government introduced destocking policy in the whole Ukambani region. Korir (1991) describes Akamba protests in 1937 which was against the government's use of force by the government to destock and confiscate livestock. This is a clear indication that the colonial government never bothered about the welfare of the people.

In 1948, the colonial government decided that the Endau forest should be protected and evicted all people from the forest in the same year. While the local population and chiefs were unhappy about the eviction, they had little power to protest or voice their concerns against the colonial District Commissioner. The colonial administrators used their own power and discretion to declare forest reserve. CICERO Report (2006). The report further gives an account of a visit by the divisional forest officer and the Forester Machakos and their tour of the entire Kitui district in September, 1948. After this tour, the two officers decided to ask the L.N.C to declare certain hills and ranges as reserves by March 1949. The list of these hills and ranges is given as Endau, Mutonguni, Mutito, Matha and Ndhoani. Following the above orders, the Endau hill, the main catchment area in Kitui East Sub County, was gazetted. It was to be owned by the government, and managed 
by the Forest Department. Eriksen. Et al(2006) attest to that by emphasizing that the Endau Hilltop Forest is a gazette forest managed by the government as a catchment area and ecologically sensitive ecosystem. These policies had a particularly negative effect on interactions between the farmers and the herders in Kitui East Sub County as they excluded farmers and herders in the region from important sources of water, forest products and drought grazing areas and limited the area available for cultivation. This played a key role in creating conflict that has been experienced repeatedly in Kitui East Sub County that further impede flexible interactions and socio-economic development in the study area.

Another colonial development was the swynnerton Plan. In 1954, the colonial government implemented the Swynnerton Plan, a land reform program that continues to shape the evolving landscape in Ukambani and the rest of Kenya. The Swynnerton Plan was made to bring reforms in land tenure, consolidate fragmented holdings and issue freehold title to encourage the intensification and development of African commercial agriculture (Bradshaw, 1990). The above policies thus, excluded pastoralists from many of their traditional grazing areas and restricted livestock movement by encouraging private land ownership. The colonial laws also excluded pastoral populations from the dairy and livestock markets. As a result, populations were disenfranchised and impoverished. This study established that some of the land tenure systems created during colonialism are still present today.

Mwikali (2018) observes that another factor which affected the relationship between the farmers and the herders in the region by the colonial government was the introduction of indirect rule which necessitated the creation of the position of the colonial chiefs. Before the imposition of colonial rule, Kenya had no trans-ethnic leaders and also had few ethnic political structures. Authority was personal and local, a function of age, lineage, supernatural abilities, wealth and leadership skills, supported by the communal wisdom of elders and the physical power of young men. Age sets or grades (communities of similarly aged men) collectively moved into new roles as children became warriors, then elders and senior elders. Some communities created semi-elective chiefs, but most did not choose a formal head. All societies were gerontocratic and relatively egalitarian, and all relations were personalized.Hornsby (2012)

Similarly, Waweru, (2006) points out that the colonial system created institutional gaps by weakening the African Traditional authorities. He further observes that the absence (or incompetence) of authorities' hierarchies to enforce rules, asks for new or improved institutions to bridge those gaps. These institutions are based on statutory or customary law, or a mixture of these types of law. Customary law can be described as: "indigenous African legal rules, procedures, institutions, and ideas". Related to this are the differences between traditional and 'modern' authorities: Traditional authorities have their roots in tradition and culture for their legitimacy, whereas in 'modern' societies, legitimacy of authorities relies on a legal (written) framework, with leadership often based on democratic principles (Lutz \& Linder, 2004).

This loss of authority of elders has also affected the nature of conflicts. The authority of elders to settle conflicts relied on three main sources: "(i) control of access to resources/ marriage; (ii) being part of a large-cross clan, cross-ethnic, cross generation network; (iii) supernatural legitimacy. These sources of power also indicate certain limits; for instance, conflicts which are larger than the network of the elders, conflicts which arise about new resources over which elders traditionally do not have legitimacy (e.g. boreholes or formalized land tenure), or when actors are not depending on economic resources managed by elders Krätli \& Swift, 1999, p.31).

In addition, Adams \& Bradbury (1995) assert that one of the main legacies of colonialism was the introduction of modern weaponry in Africa resulting in more destructive relations between certain ethnic groups. They add that colonialism precipitated the collapse of ancient principles of 'balanced reciprocity' in the practice of warfare between ethnic groups, and thereby warfare changed from being a means to adapt to new circumstances to an agent for the outright destruction of other groups. From this, it is clear that modern weapons to some extent have led to conflicts in the study area.

The colonial Kenya was divided into districts and assigned to ethnic groups. The authorities-controlled movement by making it illegal to cross district boundaries without a special pass. The issue of movement of people during drought illustrates how national and local politics influenced decisions that may have directly undermined local peace and coexistence. The colonial government Restricted the movement of pastoral communities, which was through actions by district administrations and local politicians in particular. This is confirmed by the Kenya National Archives (KNA, 1935) information which revealed communication between the colonial chiefs and the District Commissioners of Kitui and the neighbouring Tana River District. In one of the letters, where the later had written to the former requesting him to restrict the herders from entering Kitui District in search for pasture. This created bitter enmity between the herders and the farmers. The above trends are indicative of the colonial government having played a very big role in worsening the strained relations between the farmers and the herders in the study area.

\subsection{President Kenyatta Era (1963 - 1978)}

On 12 December 1963, Kenya attained independence from the United Kingdom (UK). At a ceremony on 11 December, in front of the Duke of Edinburgh, Colonial Secretary Duncan Sandys and 200,000 Kenyans, Jomo Kenyatta received Kenya's articles of independence. (Hornsby,2012).Kenyans welcomed the reality of independence with absolute exuberance propelled by the promises of political, social and economic ownership and advancement by the ruling political elite. The phase of nationalization and Africanization had entered the pragmatic stage. The immediate skewed allocation of resources; land included, and other opportunities divided the Kenyan communities into the dichotomy of inclusive and exclusive political domains. (Nasong'o and Murunga, 2007). Consequently,there was ethnic tension and suspicion amongst Kenyan communities. As such, neighboring communities viewed each other with suspicion. This became a crucial basis to farmer-herder conflict in Kitui East Sub County.

Further, the practice of favoring the most productive regions which had been encouraged by the colonial government continued even after Kenya became independent in 1963. The colonial government had done this with the 
expectation that development would 'trickle down to other areas. This was a practice during the colonial era where the British rulers used a policy of pacification for the hinterlands and focused their development efforts mainly on the more fertile Central Highlands foremost occupied by white settlers, (Foeken et al., 2000). However, to this date, communities in the hinterlands often feel marginalized. Because of weak governance, rural communities have protected themselves and are often well armed through proliferation of small arms. (Krätli \& Swift, 1999). The proliferation of small arms is especially true for the pastoral community's in Kitui East Sub County.

Whilst most attention was focused on the former white highlands, individual land registration, consolidation and the issue of land titles continued in the former reserves, with equally dramatic effects. The new government believed, as had the old, that individual title and the consolidation of fragmented holdings were essential for long-term agricultural improvement, and reduced the cost of land litigation and the fear of land expropriation. (Hornsby, 2012). This had the effect of preventing both the farmers and the herders in Kitui East Sub County from their communal land which they were using for cultivation and grazing. Subsequently, they started clashing over the limited available land.

The Kenyatta government also had a significant task in the escalation of the farmer-herder conflict. Some leaders during this era used the government agencies as instruments in their own (economic) competition. For instance, chiefs started using the police (a 'product 'of nation-states) to keep out foreign pastoralists, and this was gradually seen as legitimate(Warurii, 2015). As indicated, during the interviews, in Kitui East Sub County, upon Kenya's independence from British rule in 1963, many things changed. Several formal policies which have contributed to impeding interaction in the dry lands were introduced for instance; a key feature of the Kenyatta government policy in the dry was the efforts to sedentarise pastoralists. As a consequent, depriving them of the freedom of seasonal migration to search for pasture and water during dry seasons.

Korir (1991) describe the period just after independence when the Kenyatta government introduced a policy regime for the dry lands where soil conservation regulations remained in force. Post-independence policies then increasingly focused on experimentation with various development plans for the dry lands. These included policies and enactment laws emphasizing environmental conservation and improvement to livelihood. For example, through agricultural education, training and extension work. Hence, focus only remained on prote76NMHJYUcting the environment, controlling local resource use and introducing new, more 'modern', techniques rather than facilitating existing livelihood activities such as pastoralism. At the same time, there have been few efforts to update and strengthen policies to facilitate livestock production and crop production despite great changes on economic framework conditions in the study area.

\subsection{President Moi Era (1978 - 2002)}

Jomo Kenyatta, the founding president of Kenya, passed away in August 1978 after fourteen years as the head of state. His successor was Daniel Arap Moi. (Oyugi et al, 2003)On assuming office, President Moi assured Kenyans, that he would follow the footsteps of his predecessor in fostering national unity. True to the literal meaning of "Nyayoism" (Swahili for "footsteps") which became his philosophy, Moi ensured continuity of the principal ideals, policies and philosophies such as "African Socialism" and "Harambee"which had been the hallmark of the Kenyatta era. Critics, however, argue that Nyayoism led Moi to perfect most of the negative practices predominant in the closing years of the Kenyatta era such as neo-patrimonialism and corruption. (Nasong'o and Murunga, 2007).

Like his predecessor, Moi navigated the ethnic route by gradually dismantling all his rivals. State patronage became overtly ethnically based with opposition areas completely neglected in economic and infrastructural development. Moi asserted siasa mbaya maisha mbaya (Warurii, 2012). This meant that citizens and Kenya regions which did not show loyalty to him and the KANU government risked being consigned to economic and political oblivion. By 1981, the institution of the president had transformed from an imperial presidency to a personal state. Moi developed a personality cult where socio-economic prosperity at individual and societal levels of Kenyans greatly depended on personal political loyalty to him (Nasong'o and Murunga, 2007). Therefore, development in the area deemed not to be loyal to his government failed to get any development projects. Kitui East Sub County was therefore discriminated development wise leading to loss of livelihood and a vicious circle of poverty

The clamor for multipartyism was a crucial turning point in ethnic relations in the country. In the early 1990s, the KANU government went as far as instigating ethnic violence in order to portray the multi-party system as inappropriate for Kenya. Ethnic cleansing was introduced in order to eliminate opposition in "KANU-only zones. Notable areas which were affected were rift valley and coast provinces. (Oyugi et al, 2003). Although the study area was not directly affected, the political incitement and tension of the time played a crucial role in motivating the two groups into attacking one another.

The trend has been a permanent feature of all the elections in Kitui East Sub County even in the subsequent elections. During an oral interview with the Somali spokesman, respondent observed that during political campaigns, the political party which a certain community is supporting is used as a tool to set one community against the other. For instance, in 2007 elections, almost all the Akamba supported Kalonzo Musyokas ODM-Kenya party while most of the herder community supported Raila Odingas ODM. This was enough reason for the herder communities to be attacked by the farmers.

Orma women leader reviewed that individual candidates and political parties go to the grassroots to get votes, using every opportunity to sell their political agenda, including at funerals, public meetings and local markets. They also spell out the plans they have for their constituencies at functions organized by the provincial administration. Development funding (and promised investments in schools, dispensaries and other infrastructure) is therefore used to mobilize political support and strengthen the power of local politicians, which contributes to social inequities. 


\subsection{President Kibaki Era (2002 - 2013)}

On 30 December 2002, Kibaki was inaugurated as Kenya's third president; this awoke more hope in Kenyans than any since 1963. Forty years after independence, expectations were high and the NARC government had huge goodwill, both domestically and internationally (Hornsby, 2012)

The Kibaki government was characterized by the introduction of the constituency development fund (CDF). This was meant to enable the Members of Parliament to initiate development in their constituencies. Information from focused group discussion indicated that the political changes at the national level, involving democratization and decentralization of development funding through creation of the CDF and the local authorities transfer fund, had provided more investments and influence. There were a range of new and ongoing projects in the area. Dispensaries and schools were built, and equipped with the necessary facilities to provide the intended services. During the interviews several of the Akamba farmers expressed that these developments made them feel that their interests and needs had been considered, which may have contributed to local support for the Kibaki government during the 2007 elections.

In August 2010, a new constitution was adopted after a lengthy process that saw many stops and adjustments along the road. The document was approved in a national referendum (Kramon \& Posner, 2011). This new constitution has altered various aspects of the Kenyan society.

One of the most important and new elements in the 2010 constitution is the concept of devolution, with powers being transferred from the central government, and specifically the President, to new county governments.(Hornsby,2012)Kramon \& Posner (2011) have reported that Counties receive at least 15 per cent of the national government's revenues, and are responsible for several tasks such as primary health care, implementation of agricultural policy and management of county level transportation. Resource distribution to the counties is governed by the Senate, whereas this was earlier managed by the different ministries. It is hoped that this will go a long way in initiating development which will avert the farmer-herder conflicts inKitui East Sub County hence averting conflicts in the region.

\section{Conclusion}

The study examined the historical trends on the farmer-herder conflicts in Kitui East Sub County. The study found out that the introduction of colonial land policies in order to create room for the white high lands had a far-reaching impact on the production systems of the Kenyan communities. This is due to the fact that the reserves which were created by the colonial government for the Africans were not sufficient for their food production. In the study area, this led to overcrowding and over grazing which in turn led soil erosion. Measures undertaken by the colonial government to curb soil erosion led to the lack of enough cultivating and grazing room for both the farmers and the herders in the study area. Consequently, this led to conflicts between the local communities of Kitui East Sub County.

In the post independent era, the challenges of independence changed the relationships between ethnic communities in Kenya during the Jomo Kenyatta presidential era. Inter-ethnic conflicts mostly limited to cattle rustling were poorly managed during this period. The Kenyatta period was also characterized by the marginalization of semi-arid regions like Kitui East Sub County. This led to poverty which further escalated the competition over scarce resources leading to even more violent conflicts.

During the Moi regime, ethnic tensions increased. This was due to the fact that his regime was characterized by ethnic discrimination where the communities which did not support him were discriminated against in terms of development. Further, the 1992 transition to multi partysm did not augur well with the Moi government. Consequently, his government instigated ethnic violence against the communities. In Kitui East Sub County, the communities that supported certain political parties found themselves being attacked.

In the Kibaki era, the introduction of the Constituency Development Fund (CDF) brought some new hope to the local communities as they deemed them capable of providing solutions to the water problems which is the major cause of their conflicts. The new Constitution of Kenya amalgamated in 2010 introducing the county governments is also expected to help in initiating projects necessary for poverty eradication and eventual end to the perennial conflicts in Kitui East Sub County.

In conclusion, the study argues that the colonial capitalism economy, the deconstruction of the colonial state and the consolidation of power in the post-independence era all depict the structural violence theory. The marginalization by the four regimes from the colonial era to Kibaki era has led to competition over the limited resource culminating to violent conflict in the study area. The result of this is socio-economic decline hindering the local communities from meeting their basic needs as stated by the structural violence theorists.

\section{Recommendations of the Study}

In view of the above conclusions, this study makes the following recommendations to the National government, County government and peace Committees.

- Both the County government and national government should work together to see to it that drilling of more water points is done in all the villages of Mutitu sub County. These will avert frequent experienced conflicts during dry spells as a result of water competition for the livestock, irrigation and domestic use.

- There is need to address the proliferation of illicit weapons by strengthening the SALW agenda with intention to limit their flow and ownership among communities in Mutitu sub County of Kitui County.

- Political leaders should influence their communities positively since they determine and influence the escalation or de-escalation of violence or inter-ethnic conflicts. 
- There is need to ensure adequate representation of marginalized groups in government arms like the civil service, cabinet and in the army. This will ensure that they are not side-lined in government, which is an important factor in policy making.

- Provision of quality infrastructure would generate employment through access to market by small scale holders and entrepreneurs. Roads should be constructed and communication network restored in the region making it accessible. This will lead to improved physical infrastructure which in turn will lead to better increasing interaction between the warring communities.

\section{References}

i. Adams, M. and Bradbury, M. (1995), Conflicts and Development: Organizational Development in Conflict Situation. Oxfam Discussion Paper N4. Oxfam UK and Ireland) Oxford.

ii. CARITUS KITUI (2012) Malalani - Twambui Area. The Akambas and Somali Conflict. Report at Mwingi Workshop 3rd - 4th August 2012 at Ideal Palace, Kitui County

iii. CICERO Report 2006:01 Vulnerability to Climate Stress - Local and Regional Perspectives Proceedings of Two Workshops January 27-28, 2005, World Agroforestry Centre, Gigiri, Nairobi and February 14, 2005, KEFRI Research Centre, Kitui

iv. Cohen, L., Manion, L., \& Morrison, K. (2007). Research methods in education. London: Routledge.

v. Collier, P. et al (2003): "Breaking the Conflict trap: Civil War and Development Policy". A World Bank Policy Research Report (26121)

vi. Cramer, C. (2006): Civil War is Not a Stupid Thing: Accounting for Violence in Developing Countries. London, Hurst \& Company.

vii. Eriksen, S., and Lind, J., 2009. Adaptation as a Political Process: Adjusting to 43(5). 817835.Doi:10.1007/ S00267008-9189-0.

viii. Eriksen, S., Gachathi, F.N., Muok, B., Ochieng, B. and Owuor, B., (2006). Synergies in Biodiversity Conservation and Climate Change Adaptation: The Case of Hilltop Forests in Kitui, Kenya. Putting People back into Nature. Lessons from Savannas and Dry Forests, Mistry, J. And Berardi A. (Eds). Ashgate, Aldershot, UK.187-226. Evans Brother (Kenya) Limited.

ix. Foeken, D., Owuor, S. \& Klaver, W. (2000). Leiden. African Study Centre. Crop Cultivation in Nakuru Town, Kenya: Practice and Potential.

x. Galtung, J. (1990) Cultural Violence' 27.3 Journal of Peace Research 291-305.

xi. Hornsby, C. (2012). Kenya: A History since Independence. London: I.B. Tauris\& Co Ltd

xii. Juma, M.K. (2000). Unveiling Women as Pillars of Peace Building in Communities Fractured by Conflict in Kenya. An interim report for management development and governance division bureau for development policy, UNDP, May 2000.

xiii. Justino, P. (2007). On the Links between Violent Conflict and Household Poverty: How Much Do We Really Know, MICROCON Research Working Paper 1.159-217

xiv. Kitui County Village Bill (2014): Bill for Introduction into Kitui County Assembly. Special Issue.

xv. KNA/ DC/ KTI/ 3/ 1/ 34 Various Letters Written by the Local Administration Barring Certain Individuals and / or Groups of People from Entering the Kitui District.

xvi. Korir, M.K. (1991). History of Environmental Management in Kenya. Gaining Ground: Institutional Innovations in Land Use Management in Kenya, Kiririo, A and Juma, C. (Eds). Rev.Edition, Acts Press, African Centre for Technology Studies, Nairobi.

xvii. Kramon, E. \& Posner, D. (2011). "Kenya’s New Constitution”. Journal of Democracy.

xviii. Kratli, S\& Swift, J. Understanding and Managing Pastoral Conflict in Kenya. Uk. Institute of Development Studies.

xix. Lind, J., and Eriksen, S. (2006). The impacts of conflict on household coping strategies: evidence from Turkana and Kitui Districts in Kenya. DieErde, London: Routledge.

xx. Lutz, G.\&Linder, W. (2004). Traditional Structures in Local Government. Berne. Institute of Political Science.

xxi. Matheka, R. (1992) The Political Economy of Famine: Ecology and History in Machakos District During the Colonial Era. Master Thesis. Kenyatta University.

xxii. Mugenda, O., and Mugenda, A. (2003), Research Methods; Quantitative and Qualitative Approaches. ACTS, Nairobi.

xxiii. $\quad$ Murunga, R. \& Nasong'o, S. (2007). The Struggle for Democracy. London. Zed Books.

xxiv. Mwendwa, D. (2014). Challenges Facing Curriculum Implementation of Inclusive Education in Public Secondary Schools in Mutitu Sub County of Kitui County,Kenya.

xxv. Mwikali, W. (2018). Farmer-Herder Conflict and the Socio-Economic Development of Local Communities in Mutitu Sub County of Kitui County, Kenya (1963-2013)

xxvi. Ochieng, W. R (1985). A Modern History of Kenya. Nairobi: Macmillan Educational

xxvii. Opiyo, F.E. O., Mureithi, S.M., \& Ngugi, R.K. (2011): The Influence of Water Availability on Pastoralist's Resource Use in Kitui and Mwingi Districts of Kenya. Journal of Human Ecology.

xxviii. Orodho A.J. (2009). Techniques of Writing Research Proposals and Reports in Education and Social Sciences. Nairobi: KANE 2 J.A

xxix. Orodho, A.J. (2003). Essentials of Educational and Social Sciences Research Method. Nairobi: Masola Publishers.

xxx. Oyugi, W., Wanyande, P. \& Mbai, C. (2003). The Politics of Transition in Kenya: from KANU to NARK. Nairobi. Heinrich Boll Foundation Publishers. 
xxxi. Seddon, D., and Sumberg, J. (2010). Conflict between Farmers and Herders in Africa: An Analysis: Available atWww.Nrinternational.Co. Uk and Retrieved on October, 6th 2011.

xxxii. Sen, A., (1999) Development as Freedom. Oxford: Oxford University Press.

xxxiii. Sengupta, A. Second Report of the Independent Expert on the Right to Development, To the Human Right Commission, A/ 55/ 306

xxxiv. Simiyu, V. (1974). "Land and Politics in Ukambani from the End of the 19th Century Up To 1933". Présence Africaine Editions. No. 89. pp. 101-146.

xxxv. Warurii, F (2008) Inter-Ethnic Conflicts: Trends, Causes, Effects and Interventions in Rumuruti Division of Laikipia County, Kenya (1963 - 2010) Masters thesis, Kenyatta University

xxxvi. Waweru, P. (2006). Continuity and Change in Samburu Pastoralism. Under Colonial Rule, 1909-1963. Egerton University. LAP LAMBERT Academic Publishing.

xxxvii. Were, G.S. \& Wilson, D.A. (1987). East Africa through a Thousand Years. Nairobi: 